\title{
PERBEDAAN ASUPAN DAN STATUS GIZI \\ PADA PASIEN STROKE HEMORAGIK DAN NON HEMORAGIK DI RSUD PROF. DR. MARGONO SOEKARJO
}

\author{
The Differences Of Nutritional Intake and Status \\ On Hemmorrhage Stroke Patients and Ischemic \\ At Prof. Dr. Margono Soekarjo Hospital
}

\author{
Deviana Ayushinta Sani Siregar ${ }^{1}$, Saryono $^{2}$, Nurekta Yuristrianti ${ }^{3}$ \\ ${ }^{1}$ Program Studi Ilmu Gizi, Universitas Jenderal Soedirman, ${ }^{2}$ Jurusan \\ Keperawatan, Bagian Biokimia, Universitas Jenderal Soedirman, ${ }^{3}$ Instalasi Gizi \\ RSUD Prof. Dr. Margono Soekarjo \\ Alamat korespondensi ayudeviii@gmail.com
}

\begin{abstract}
Stroke is a disease of the brain in form of nerve dysfunction locally or globally, appears in sudden, progressive, and fast. World Health Organization (WHO) estimates that the stroke caused 5.7 million deaths in the world. Stroke can be caused by bleeding or clotting. The wide of diameter of the lesions in patients with hemorrhagic stroke increased $20 \%$ compared with the extent of the lesion in patients with ischemic stroke. Prevalence of malnutrition significantly more general in hemorrhagic stroke (62\%) than ischemic stroke (25\%). The impact of malnutrition in stroke patient can increase mortality after three months onset of stroke. The research conducted in Prof. Dr. Margono Soekarjo hospital, using a cross sectional study program and using purposive sampling technique. The total of sample used is 44 people, consisting of a group of non-hemorrhagic stroke and hemorrhagic stroke. The analysis of data is using $t$ independent bivariate test. The group average intake levels of hemorrhagic stroke is lower than ischemic stroke. According to the anthropometry index MUAMC and BMI, the hemorrhagic stroke group average is lower than the ischemic stroke.According to the result of statistic analysis, the researcher did not find a significant difference on the intake of nutrient and nutritional status in hemorrhagic stroke and ischemic stroke patient.
\end{abstract}

Keywords: Hemorrhage stroke, ischemic Stroke, nutritional intake, nutritional status

\begin{abstract}
ABSTRAK
Stroke adalah penyakit pada otak berupa gangguan fungsi saraf lokal atau global, munculnya mendadak, progresif, dan cepat. World Health Organitation (WHO) memperkirakan bahwa stroke menyebabkan 5,7 juta kematian di dunia. Stroke dapat disebabkan karena perdarahan atau bekuan. Luas diameter lesi pada pasien stroke hemoragik mengalami peningkatan $20 \%$ bila dibandingkan dengan luas lesi pada pasien stroke non hemoragik. Prevalensi kekurangan zat gizi secara signifikan lebih umum pada kelompok stroke hemoragik (62\%) dibandingkan dengan kelompok stroke non hemoragik (25\%). Dampak yang ditimbulkan dari status gizi kurang pada pasien stroke yaitu dapat meningkatkan mortalitas setelah tiga bulan serangan stroke. Penelitian dilakukan di RSUD Prof. Dr. Margono Soekarjo, menggunakan racangan penelitian cross sectional dan menggunakan teknik purposive sampling. Total sampel yang digunakan sebanyak 44 orang, terdiri dari kelompok stroke hemoragik dan stroke non hemoragik. Analasis data menggunakan uji bivariate $\mathrm{t}$ independent. Rata-rata tingkat asupan kelompok stroke hemoragik lebih rendah dibandingkan dengan kelompok stroke non hemoragik. Berdasarkan indeks antropometri LOLA dan IMT, kelompok stroke hemoragik memiliki rata-rata yang lebih rendah dibandingkan dengan kelompok stroke non hemoragik. Berdasarkan hasil analisis statistik tidak terdapat perbedaan yang signifikan asupan dan status gizi pada pasien stroke hemoragik dan non hemoragik.

Kata Kunci: Stroke Hemoragik, Stroke Non Hemoragik, Asupan Zat Gizi, Status Gizi
\end{abstract}




\section{Pendahuluan}

Stroke adalah penyakit pada otak berupa gangguan fungsi saraf lokal atau global, munculnya mendadak, progresif, dan cepat (WHO, 2016). Stroke dapat disebabkan karena perdarahan atau bekuan. Stroke karena perdaharan atau sering disebut dengan stroke hemoragik ( $\mathrm{SH})$ terjadi apabila lesi vascular intrasereberum mengalami ruptur sehingga terjadi perdarahan ke dalam ruang subaraknoid atau langsung ke dalam jaringan otak. Stroke non hemoragik (SNH) terjadi akibat adanya obstruksi atau bekuan di satu atau lebih arteri besar pada sirkulasi sereberum (Price dan Wilson, 2012).

Prevalensi penyakit stroke di Indonesia adalah sebesar 57,9\%, sedangkan prevalensi penyakit stroke di Jawa Tengah adalah sebesar 12,3\% (Kemenkes RI, 2013). Prevalensi stroke hemoragik di Jawa Tengah tahun 2012 mengalami peningkatan 0,03\% dari tahun 2011. Sedangkan prevalensi stroke non hemoragik pada tahun 2012 mengalami penurunan sebesar 0,09\% dibanding tahun 2011 (Dinkes Jateng, 2012). Jumlah kasus stroke di Rumah Sakit Umum Daerah (RSUD) Prof. Dr. Margono Soekarjo Purwokerto menunjukkan semakin
J.Gipas, Mei 2018, Volume 2 Nomor 1 ISSN 2599-0152 eISSN 2599-2465 http://jos.unsoed.ac.id/index.php/jgps meningkat setiap tahunnya. Perhitungan jumlah kasus stroke pada tahun 2010, 2011 dan 2012 secara berturut-turut mencapai 924, 1019, dan 1061 untuk semua kasus stroke baik stroke hemoragik maupun stroke non hemoragik.

Penelitian Choi et al., (1998) melaporkan bahwa prevalensi kekurangan zat gizi secara signifikan lebih umum pada kelompok stroke hemoragik (62\%) dibandingkan dengan kelompok stroke non hemoragik (25\%). Dampak yang ditimbulkan dari status gizi kurang pada pasien stroke yaitu dapat meningkatkan mortalitas setelah tiga bulan serangan stroke (Wijayanti, 2012). Penelitian Poels, et al. (2006) melaporkan bahwa $73 \%$ pasien stroke mengalami malnutrisi. Berdasarkan laporan penelitian, pasien pasca stroke dengan undernutrition memiliki risiko meninggal lebih tinggi dibandingkan pasien pascastroke dengan nutrisi yang baik (Martineau et al., 2005).

Hingga saat ini, perbedaan asupan dan status gizi pada pasien stroke hemoragik dan stroke non hemoragik yang menjalani rawat jalan di RSUD. Prof. Dr. Margono Soekarjo belum pernah dilakukan, oleh karena itu peneliti ingin meneliti 
apakah terdapat perbedaan status gizi pada pasien stroke hemoragik dan stroke non hemoragik di RSUD. Prof. Dr. Margono Soekarjo.

\section{Metode}

Penelitian ini menggunakan metode rancangan cross sectional, dilakukan di RSUD Prof. Dr. margono Soekarjo selama kurang bulan Juli-Agustus 2016. Populasi yang dalam penelitian ini adalah pasien stroke hemoragik dan pasien stroke non hemoragik yang menjalani rawat jalan di RSUD Prof. Dr. margono Soekarjo selama bulan JuniJuli 2016.

$$
\text { Banyaknya sampel yang }
$$
digunakan pada penelitian ini adalah 22 orang dari setiap kelompok, total sampel dari penelitian ini adalah 44 orang. Menggunakan teknik purposive sampling dalam http://jos.unsoed.ac.id/index.php/jgps pengambilan sampel. Penelitian ini menggunakan dua kelompok sampel, yaitu kelompok stroke hemoragik dan kelompok stroke non hemoragik, dengan kriteria inklusi, yaitu pasien stroke yang menjalani rawat jalan di RSUD Prof. Margono Soekarjo, dapat berdiri, memiliki kesadaran penuh, dan pasien dengan gula darah normal, sedangkan kriteria eksklusi terdiri dari, tidak bersedianya menjadi responden, pasien dengan disfagia, dan pasien dengan dispepsis.

Variabel terikat yang diteliti pada penelitian ini adalah status gizi yang dihitung menggunakan indeks antropometri LOLA dan IMT, serta tingkat asupan gizi yang diukur menggunakan recall 2x24 jam. Analisis data bivariat menggunakan $t$ independent.

Hasil dan Pembahasan

Tabel 1. Karakteristik Usia Responden Stroke Hemoragik dan Non Hemoragik

\begin{tabular}{ccc}
\hline Karkteristik & Jenis Stroke & Mean \pm SD \\
\hline Usia (tahun) & Stroke Hemoragik (SH) & $62,32 \pm 7,04$ \\
& Stroke Non Hemoragik (SNH) & $59,09 \pm 9,74$ \\
\hline
\end{tabular}


Tabel 2. Karakteristik Jenis Kelamin Responden Stroke Hemoragik dan Non Hemoragik

\begin{tabular}{lccc}
\hline \multirow{2}{*}{ Jenis kelamin } & \multicolumn{2}{c}{ Jenis Stroke } & \multirow{2}{*}{ Total } \\
\cline { 2 - 3 } & Stroke Hemoragik & Stroke Non Hemoragik & \\
\hline Laki-laki & 9 & 13 & 22 \\
Perempuan & 13 & 9 & 22 \\
Total & 22 & 22 & 44 \\
\hline
\end{tabular}

Distribusi frekuensi didominasi oleh jenis kelamin berdasarkan Tabel 1. Menunjukan perempuan, sedangkan pada bahwa usia semua responden kelompok stroke non hemoragik tergolong dalam lanjut usia. didominasi oleh jenis kelamin lakiBerdasarkan Tabel 2. menunjukan laki. pada kelompok stroke hemoragik

Tabel 3. Karakteristik Penyakit Penyerta Responden Stroke Hemoragik dan Non Hemoragik

\begin{tabular}{lcccc}
\hline \multirow{2}{*}{ Penyakit Penyerta } & \multicolumn{3}{c}{ Jenis Stroke } \\
\cline { 2 - 5 } & \multicolumn{2}{c}{ SH } & SNH \\
\cline { 2 - 5 } & $\mathbf{n}$ (orang) & \% & n (orang) & \% \\
\hline Cardiac Heart Failure (CHF) & - & - & 1 & 4,55 \\
CHF dan Hipertensi Heart Disease (HHD) & - & - & 1 & 4,55 \\
Diabetes Mellitus-2 & 1 & 4,55 & - & - \\
Hipertensi & 21 & 95,45 & 16 & 72,73 \\
Ischemic Heart Disease (IHD) dan HHD & - & - & 1 & 4,55 \\
Ostheathritis (OA) & - & - & 2 & 9,09 \\
Parkinson & - & - & 1 & 4,55 \\
\hline
\end{tabular}

Tabel 3. menunjukan lebih dari $50 \%$ responden dari kedua kelompok memiliki penyakit penyerta hipertensi. Hasil indeks
Barthel pada Tabel 4. menunjukan lebih dari 50\% responden dari kedua kelompok tergolong mandiri.

Tabel 4. Karakteristik Indeks Barthel Responden Stroke Hemoragik dan Non Hemoragik

\begin{tabular}{lcccc}
\hline \multirow{2}{*}{ Hasil Indeks Barthel } & \multicolumn{4}{c}{ Jenis Stroke } \\
\cline { 2 - 5 } & \multicolumn{2}{c}{ SH } & \multicolumn{3}{c}{ SNH } \\
\cline { 2 - 5 } & $\mathbf{n}$ (orang) & $\%$ & $\mathbf{n}$ (orang) & $\%$ \\
\hline 0-20 (ketergantungan penuh) & - & - & - \\
21-61 (ketergantungan berat) & 7 & 31,8 & - & - \\
62-90 (ketergantungan sedang) & 4 & 18,2 & 2 & 9,1 \\
91-99 (ketergantungan ringan) & - & - & - & - \\
100 (mandiri) & 11 & 50 & 20 & 90,9 \\
\hline
\end{tabular}


Berdasarkan Tabel http://jos.unsoed.ac.id/index.php/jgps
njukan sebanyak $36,4 \%$ dari

Menunjukan lebih dari 50\% responden dari kedua kelompok belum memiliki tingkat asupan energi, protein, dan lemak yang baik. Hasil pengukuran status gizi pada Tabel 6. Berdasarkan indeks antropometri LOLA masing-masing kelompok memiliki statug gizi yang normal, sedangkan berdasarkan indeks antropometri IMT menunujukan lebih dari $50 \%$ responden dari kedua kelompok memiliki status gizi normal.

Tabel 5. Karakteristik Tingkat Asupan Dibandingkan dengan Standar Responden Stroke Hemoragik dan Non Hemoragik

\begin{tabular}{|c|c|c|c|c|}
\hline \multirow{2}{*}{ Kategori } & \multicolumn{2}{|c|}{ SH } & \multicolumn{2}{|c|}{ SNH } \\
\hline & n (orang) & $\%$ & n (orang) & $\%$ \\
\hline \multicolumn{5}{|l|}{ a. Energi } \\
\hline Lebih $(>100 \%)$ & 10 & 45,5 & 16 & 72,2 \\
\hline Baik (80-100\%) & 3 & 13,6 & - & - \\
\hline Kurang $(<80 \%)$ & 9 & 40,9 & 6 & 27,3 \\
\hline \multicolumn{5}{|l|}{ b. Protein } \\
\hline Lebih $(>100 \%)$ & 7 & 31,8 & 8 & 36,4 \\
\hline Baik (80-100\%) & 6 & 27,3 & 5 & 22,7 \\
\hline Kurang $(<80 \%)$ & 9 & 40,9 & 9 & 40,9 \\
\hline \multicolumn{5}{|l|}{ c. Lemak } \\
\hline Lebih $(>100 \%)$ & - & - & - & - \\
\hline Baik (80-100\%) & - & - & - & - \\
\hline Kurang $(<80 \%)$ & 22 & 100 & 22 & 100 \\
\hline
\end{tabular}

Analisis bivariat pada penelitian ini menggunakan uji t independent. Hasil analisis bivariat dalam penelitian ini disajikan pada Tabel 7. dan Tabel 8.

Tabel 6. Karakteristik Status Gizi Dibandingkan dengan Standar Responden Stroke Hemoragik dan Non Hemoragik

\begin{tabular}{lcccc}
\hline \multicolumn{1}{c}{ Kategori } & \multicolumn{2}{c}{ SH } & \multicolumn{2}{c}{ SNH } \\
\cline { 2 - 5 } & n (orang) & \% & n (orang) & \% \\
\hline LOLA & 3 & 13,6 & 4 & 18,2 \\
Malnutrisi berat $(<70 \%)$ & 5 & 22,7 & 2 & 9,1 \\
Malnutrisi sedang $(70-79,9 \%)$ & 6 & 27,3 & 8 & 36,4 \\
Malnutrisi ringan $(80-89,9 \%)$ & 8 & 36,4 & 8 & 36,4 \\
Normal $(\geq 90 \%)$ & & & & \\
IMT & 1 & 4,5 & 2 & 9,1 \\
Kurus $(<18,4)$ & 16 & 72,7 & 13 & 59,1 \\
Normal $(18,5-25)$ & 5 & 22,7 & 7 & 31,8 \\
Gemuk $(>25)$ & & & &
\end{tabular}

Tabel 7. menunjukkan tidak terdapat perbedaan asupan energi $(\mathrm{p}>0,05)$, protein $(\mathrm{p}>0,05)$, dan lemak $(p>0,05)$ pada pasien stroke hemoragik dan non hemoragik. 
Tabel 7. Perbedaan Tingkat Asupan Gizi Responden Stroke Hemoragik dan Non Hemoragik

\begin{tabular}{lcccc} 
& \multirow{2}{*}{ Kategori } & \multicolumn{2}{c}{ Mean \pm SD } & \multirow{2}{*}{ Nilai $\mathrm{p}$} \\
\cline { 2 - 4 } & & SH & SNH & \\
\hline Energi (kkal) & $1483,1 \pm 656,7$ & $1739 \pm 528,7$ & 0,162 \\
Protein (gram) & $42,6 \pm 22,6$ & $48,5 \pm 14,6$ & 0,311 \\
Lemak (gram) & $27,1 \pm 14,5$ & $33,9 \pm 13,8$ & 0,113 \\
\hline
\end{tabular}

Tabel 8. Menunjukan tidak $(\mathrm{p}>0,05)$ dan IMT $(\mathrm{p}>0,05)$ pada pasien terdapat perbedaan status gizi stroke hemoragik dan non hemoragik. berdasarkan indeks antropometri LOLA

Tabel 8. Perbedaan Status Gizi Responden Stroke Hemoragik dan Non Hemoragik

\begin{tabular}{lcccc}
\hline & Variabel & \multicolumn{2}{c}{ Mean \pm SD } & Nilai $\mathrm{p}$ \\
\cline { 2 - 4 } & & SH & SNH & \\
\hline LOLA $(\mathrm{mm})$ & $210,8 \pm 26,03$ & $212,73 \pm 32,81$ & 0,863 \\
IMT $\left(\mathrm{kg} / \mathrm{m}^{2}\right)$ & $22,8 \pm 3,69$ & $24 \pm 5,84$ & 0,243 \\
\hline
\end{tabular}

Hasil analisis statistik menggunakan uji $t$ independent pada tingkat asupan energi, protein, dan lemak pada pasien stroke hemoragik dan stroke non hemoragik secara berturut-turut diperoleh nilai $\mathrm{p}=0,162(\mathrm{p}>0,05), \mathrm{p}=$ $0,311(\mathrm{p}>0,05)$, dan $\mathrm{p}=0,113(\mathrm{p}>0,05)$, menunjukan tidak adanya perbedaan yang signifikan pada kedua kelompok.

Hasil penelitian ini menunjukan tidak adanya perbedaan tingkat asupan energi, protein, dan lemak pada pasien stroke hemoragik dan non hemoragik dikarenakan tidak terdapat perbedaan kebutuhan asupan gizi antara stroke hemoragik dan non hemoragik apabila memiliki faktor resiko yang sama, serta responden tidak mematuhi diet yang seharusnya dijalani oleh masing-masing responden. Pemberian diet pada pasien stroke disesuaikan dengan faktor resiko penyebab stroke yang dimiliki oleh setiap pasien stroke, baik stroke hemoragik maupun stroke non hemoragik (Lim dan Choue, 2013), dimana pada penelitian ini lebih dari $50 \%$ responden memiliki penyakit penyerta hipertensi. Diet $D A S H$ (Dietary Approaches to Stop Hypertension), direkomendasi untuk menurunkan tekanan darah dan asupan lemak jenuh pada pasien stroke, dimana pada diet ini konsumsi buah-buahan, sayuran, dan produk susu rendah lemak ditingkatkan (Goldstein et al., 2011). Sekitar $80-85 \%$ stroke non hemoragik yang terjasi akibat obstruksi atau bekuan di satu atau lebih arteri

Atherosklerosis menjadi salah satu penyebab tersering yang terjadinya stroke non hemoragik (Price, 2014). Perlu adanya pembatasan asupan kolesterol dan lemak, terutama lemak jenuh dalam 
penatalaksanaan diet yang dilakukan (Wahyuningsih, 2013).

Hasil analisis statistik menggunakan uji t independent pada status gizi berdasarkan LOLA dan IMT secara berturut-turut pada pasien stroke hemoragik dan stroke non hemoragik diperoleh nilai $\mathrm{p}$ $=0,863(\mathrm{p}>0,05)$ dan $\mathrm{p}=0,243(\mathrm{p}>0,05)$, menunjukan tidak adanya perbedaan signifikan pada kedua kelompok. Apabila dilihat dari rata-rata LOLA dan IMT secara berturur-turut pada kelompok stroke hemoragik dan non hemoragik memiliki perbedaan yaitu $210,8 \mathrm{~mm}$ dan $212,73 \mathrm{~mm}$ serta $22,8 \mathrm{~kg} / \mathrm{m}^{2}$ dan $24 \mathrm{~kg} / \mathrm{m}^{2}$ meskipun secara statistik tidak menunjukan perbedaan yang signifikan. Rata-rata responden telah memiliki status gizi yang termasuk pada rentang normal, hal tersebut sesuai dengan penelitian Chai, et al., 2008, bahwa rendahnya prevalensi malnutrisi pada pasien stroke mencerminkan proses asuhan gizi selama perawatan di rumah sakit. Pasien stroke tanpa membedakan subtipe dari stroke tersebut, perlu mendapatkan intervensi gizi segera setelah terjadinya serangan (Choi, et al., 1998).

Status gizi awal setelah terjadi serangan stroke secara independen berhubungan dengan outcome jangka panjang dari pasien stroke (Gariballa, 2003). Disfagia atau kesulitan menelan berhubungan terhadap asupan zat gizi (Gariballa dan Sinclair, 1998). Hasil penelitian Gordon et al., 1987, menjelaskan bahwa terjadi $43 \%$ komplikasi disfagia pada awal stroke, dan sebanyak $86 \%$ dari mereka mampu menelenan secara normal kembali setelah dua minggu.

Hasil penelitian Jørgensen, et al., 1995 menyatakan bahwa rata-rata status gizi pada kelompok stroke hemoragik lebih rendah apabila dibandingkan dengan kelompok stroke non hemoragik. Secara umum keparahan stroke lebih parah pada pasien stroke hemoragik. Luas lesi pada pasien dengan stroke hemoragik secara umum lebih besar dibandingkan dengan pasien dtroke non hemoragik. Hasil penelitian dari Copenhagen stroke study menyatakan bahwa diameter dari lesi pada pasien stroke hemoragik meningkat $20 \%$ apabila dibandingkan dengan pasien dengan stroke non hemoragik, prognosis yang lebih buruk pada pasien dengan stroke hemoragik disebabkan oleh peningkatan frekuensi perdarahan intraserebral dengan meningkatnya keparahan stroke.

Secara umum gejala yang ditimbulkan dari stroke tergantung pada besar dan letak lesi di otak, yang menyebabkan gejala dan tanda organ yang dipersarafi oleh bagian tersebut. Jenis patologi (hemoragik atau non hemoragik) secara umum tidak menyebabkan perbedaan dari tampilan gejala, kecuali 
bahwa pada jenis hemoragik seringkali ditandai dengan nyeri kepala hebat, terutama terjadi saat bekerja (Setiati, et al., 2014). Gangguan fungsi kognitif merupakan komplikasi pasca stroke yang sering terjadi tergantung dari lokasi lesi dan tingkat keparahan stroke (Warlow, et al., 2007).

\section{Kesimpulan}

Rata-rata tingkat asupan responden

kelompok stroke hemoragik lebih rendah

\section{Daftar Pustaka}

Chai, J., Chu F., Chow, T., dan Shum, N. 2008. Prevalence of Malnutrition and Its Risk Factors in Stroke Patients Residing in an Infirmity, Singapore Medical Journal, 49 (4) : 292.

Choi, K., Yang, YH., Kim, E.K., Kim, SJ. 1998. Nutritional Status in Acute Stroke: Undernutrition Versus Overnutrition in Different Stroke Subtypes. Acta Neurologica Scandinavica, 98 (3) : 18792.

Gariballa, S. 2003. Poor Nutritional Status on Admission Predicts Poor Outcomes after Stroke. American Heart Association, 34 : 1450-1456.

Gariballa, S., dan Sinclair, A. 1998. Assessment and Treatmnet of Nutritional Status in Stroke Patients, Postgrad Med J, 74 : 395399.

Goldstein, B., Bushnell, D., Adams, J., Appel, J., Chaturvedi, S., Creager A., Culebras, A., Eckel, H., Hart, G., Hinchey, A., Howard, J., Jauch, C., Levine, R., Meshcia, F., Moore, S., dan Pearson, A. 2011. Guidelines for the Primary Prevention of Stroke A Guideline for Healthcare Professionals From the American Heart Association/American Stroke Association The American Academy of Neurology. American Stroke Association.

Gordon C., Langton, H., dan Wade, D., 1987, Dysphagia in acute stroke, BMJ, 4 (295) : 411.

Jørgensen, H.S., Nakayama, H., Raaschou, H.O., Olsen, T.S. 1995. Intracerebral
J.Gipas, Mei 2018, Volume 2 Nomor 1 ISSN 2599-0152 eISSN 2599-2465

http://jos.unsoed.ac.id/index.php/jgps dibandingkan dengan kelompok stroke non hemoragik. Status gizi responden kelompok stroke hemoragik memiliki ratarata yang lebih rendah dibandingkan dengan kelompok stroke non hemoragik berdasarkan LOLA dan IMT. Hasil analisis statistik menyatakan bahwa tidak terdapat perbedaan yang signifikan asupan dan status gizi pada pasien stroke hemoragik dan non hemoragik.

Hemorrhage Versus Infarction: Stroke Severity, Risk Factors and Prognosis. Ann Neurol, 38 : 45-50.

Lim, H., dan Choue, R. 2013. Impact Of Nutritional Status And Dietary Quality On Stroke : Do We Need Specific Recommendations?. European Journal of Clinical Nutrition , 67 : 548-554.

Martineu, J., Bauer, J.D., Isenring, E., dan Cohen, S. 2005. Malnutrition Determined by The Patient-Generated Subjective Global Assessment Outcomes in Acute Stroke Patients. National Center for Biotechnology Information, 24 (6).

Poels, B.J., Brinkman-Zijlker, H.G., Dijkstra, P.U., Postema, K. 2006. Malnutrition, Eating Difficulties and Feeding Dependence in a Stroke Rehabilitation Centre. National Center for Biotechnology Information, 28 (10) : 637-643.

Price, A.S., dan Wilson, M.L. 2012. Patofisiologi Konsep Klini Prose-Proses Penyakit, Jilid 2. EGC. Jakarta.

Setiati, S., Alwi, I., Sudoyo, W., Aru, S., Marcellus, S.B., dan Syam, F.A. 2014. Ilmu Penyakit Dalam, Jilid 2. Interna Publishing. Jakarta.

Wahyuningsih, R. 2013. Penatalaksanaan Dietpada Pasien. Graha Ilmu. Yogyakarta.

Warlow, C., Gijn, VJ., Dennis, M., Wardlaw, J., Bamford, J., dan Hankey, G. 2007.

Stroke Practical Managemnet Third Edition. Blackwell Publishing. USA.

Wijayanti, A. 2012. Disfagia sebagai Faktor Risiko Status Gizi Pasien Stroke Di Ruang Rawat Inap R.S. DR. Cipto Mangunkusumo Jakarta. Tesis. Jurusan Kesehatan Masyarakat Universitas Gadjah Mada, Yogyakarta. 